\title{
Investigating Methylene Blue Adsorption and Photocatalytic Activity of ZnO/CNC Nanohybrids
}

\author{
Vu Nang An, ${ }^{1,2}$ Tran T. T. Van $\mathbb{D}^{1,2}$ Ha T. C. Nhan $\left.{ }^{1}\right)^{1,2}$ and Le Van Hieu $\mathbb{D}^{1,2,3}$ \\ ${ }^{1}$ Faculty of Materials Science and Technology, University of Science, VNU-HCM, Vietnam \\ ${ }^{2}$ Vietnam National University Ho Chi Minh City, Vietnam \\ ${ }^{3}$ Laboratory of Multifunctional Materials, University of Science, VNU-HCM, Vietnam
}

Correspondence should be addressed to Le Van Hieu; lvhieu@hcmus.edu.vn

Received 27 December 2019; Revised 13 February 2020; Accepted 28 February 2020; Published 17 March 2020

Guest Editor: Ana C. S. Alcântara

Copyright (c) $2020 \mathrm{Vu}$ Nang An et al. This is an open access article distributed under the Creative Commons Attribution License, which permits unrestricted use, distribution, and reproduction in any medium, provided the original work is properly cited.

Nanohybrids of zinc oxide/cellulose nanocrystals ( $\mathrm{ZnO} / \mathrm{CNCs}$ ) were successfully prepared by using a low cost and green method for adsorption and photocatalytic degradation of methylene blue (MB). CNCs have been derived through the hydrolysis reaction by citric/hydrochloric acid from the pure cellulose isolated from Vietnamese Nypa fruticans trunk. The influence of the $\mathrm{Zn}^{2+}$ ion concentration on the morphology, microstructure, and thermal properties as well as the photocatalytic activity of the $\mathrm{ZnO} / \mathrm{CNC}$ nanohybrids was investigated in detail. Analyses of FTIR spectra, XRD, and SEM indicated that the ZnO nanocrystals with the size of $50 \mathrm{~nm}$ formed and loaded on the surface of CNC. Based on the DRS spectra and the nitrogen adsorption-desorption isotherms (BET) analysis, the absorption of ultraviolet light with a strong absorption band around $400 \mathrm{~nm}$ was found for all the $\mathrm{ZnO} / \mathrm{CNC}$ nanohybrids, and the values of specific surface areas $\left(S_{\mathrm{BET}}\right)$ of materials can be controlled by changing the concentration ratio of $\mathrm{Zn}^{2+}$ ion and CNC. The TGA analysis demonstrated that the $\mathrm{ZnO}$ loading samples $(\mathrm{ZnO} / \mathrm{CNC})$ had the thermal degradation onset temperature higher than that of neat CNC. The effect of MB removal showed the results which were contributed not only by the adsorption ability of CNC but also by the photocatalytic activity of ZnO. The photocatalytic efficiency significantly depended on the content of $\mathrm{ZnO}$ loading. The maximum degradation of $\mathrm{MB}$ was about $95 \%$ in $150 \mathrm{~min}$ for the $\mathrm{ZnO} / \mathrm{CNC}-1.0$ sample in which the concentration ratio of zinc-precursor $\mathrm{Zn}\left(\mathrm{NO}_{3}\right)_{2} \cdot 6 \mathrm{H}_{2} \mathrm{O}$ and CNC was 1.0.

\section{Introduction}

Cellulose as one of the most abundant natural biopolymers has been widely used as a reinforcing material for fiberthermoplastic composite materials [1-5]. Cellulose nanocrystals (CNCs) prepared by acid hydrolysis of natural cellulose are typically formed of a rigid rod-shaped monocrystalline domain at different nanosizes of $1-100 \mathrm{~nm}$ (in diameter), depending on the biomass source [6]. CNCs have been using as nanofillers in polymer composites, in food and cosmetics, etc. $[7,8]$. CNCs have many advantage aspects such as excellent mechanical properties, high aspect ratio, nanoscale dimension, low cost, availability, and renewability [9]. However, monofunctional CNC can be only applied in various biomedical and photocatalytic fields since many researchers are trying to make its more functionalization such as chemical modification and doping with other nanomaterials.

$\mathrm{ZnO}$ nanoparticles ( $\mathrm{ZnO} \mathrm{NPs}$ ) were reported to have the notable optoelectronic properties, high catalytic activity for chemical and biological species, and strong antimicrobial properties for wide range of pathogens [10]. Having the band gap of $\mathrm{ZnO}$ of $3.3 \mathrm{eV}$ similar to that of $\mathrm{TiO}_{2}(3.2 \mathrm{eV}$ for anatase), the $\mathrm{ZnO}$ shows the also remarkable optical and photocatalytical properties. Therefore, $\mathrm{ZnO}$ was also found in many applications in functional optical devices, ultraviolet photodetectors, gas sensors, solar cells, ultraviolet laser diodes, and ion insertion batteries [11-14] and also in medical and pharmaceutical industries for drug delivery and cosmetics manufacturing. In other hand, one of attracting recent development of $\mathrm{ZnO}$ application in waste water treatment is for the degradation of pollutants including organic dyes, 
effluents, and also for the removal of heavy metals during waste water purification [15-17]. However, $\mathrm{ZnO}$ nanoparticles tend to aggregate due to their large surface area and high surface energy. To overtake this problem and improve nanoscale dispersion, the fabrication of $\mathrm{ZnO}$ nanoparticles in using the nanofibrillar materials (such as cellulose and its derivatives) as a substrate has attracted attention for many potential applications in different areas. Although the research on cellulose-based nanocomposites is continuously growing, there are few studies published on the synthesis of $\mathrm{ZnO}$ NPs on the cellulose substrate. These studies reported the complicated preparation methods and take a longtime process of experiment, which are not efficient for industrial application. For example, Ul-Islam et al. [18] have used three timeexperimental steps to prepare $\mathrm{ZnO} / \mathrm{CNC}$ nanohybrids by using regenerated bacterial cellulose (RBC) templates. The obtained nanohybrids showed efficient antibacterial properties, but the degradation temperatures were increased slightly by $5-10^{\circ} \mathrm{C}$ compared with neat $\mathrm{RBC}$. More recently, a twostep preparation method for $\mathrm{ZnO} / \mathrm{CNC}$ nanohybrids was reported. The first step is the preparation of CNC using hydrochloric acid hydrolysis and then the next is the formation of $\mathrm{ZnO}$ nanoparticles on the surface of the $\mathrm{CNC}$ using a precipitation method. This result was shown the relatively weak interactions between the $\mathrm{CNC}$ and $\mathrm{ZnO}$ nanoparticles due to the weak electrostatic interactions between the hydroxyl groups on the surface of the CNC and the $\mathrm{Zn}^{2+}$ $[19,20]$. The achieved $\mathrm{ZnO} / \mathrm{CNC}$ nanohybrids exhibited stronger antibacterial activity than the CNC ions. In this work, a simple, green one-step synthesis technique was applied to fabricate $\mathrm{ZnO} / \mathrm{CNC}$ hybrids at mild temperature of $80^{\circ} \mathrm{C}$ in using solely water solvent and especially Vietnamese biosource Nypa fruticans cellulose nanocrystals which were used as the biotemplate in order to improve the adsorption and photocatalytic efficiency of $\mathrm{ZnO}$ NPs. Moreover, the morphology, structure, and properties of the $\mathrm{ZnO} / \mathrm{CNC}$ nanohybrids were investigated with different ratios. This method could be used as one of the approaches for the development of cheaper and more effective technologies for industrial wastewater purification.

\section{Materials and Methods}

Nypa Fruticans trunk (NFT) was collected from muddy areas along the riverside in Ben Tre, Southwest of Vietnam. Zinc nitrate $\left(\mathrm{Zn}\left(\mathrm{NO}_{3}\right)_{2} \cdot 6 \mathrm{H}_{2} \mathrm{O}, 98 \%\right)$ and sodium hydroxide $(\mathrm{NaOH}, 96 \%)$ were purchased from Guangdong Guanghua Sci-Tech Co., Ltd., China. Formic acid (HCOOH, 90\%), hydrogen peroxide $\left(\mathrm{H}_{2} \mathrm{O}_{2}, 30 \%\right)$, and sulfuric acid $\left(\mathrm{H}_{2} \mathrm{SO}_{4}\right.$, 98\%) were procured from Xilong Scientific Co., Ltd., China.

2.1. Extraction of Cellulose from NFT. Cellulose was isolated from NFT as raw material by chemical treatment method [21]. First, the raw cellulose bulk of NFT was peeled off and cut into chunks around $30 \mathrm{~cm}$ in length and $1 \mathrm{~cm}^{2}$ of edge surface area. These chunks of NFT had been then laminated by a rolling machine before dried and splitted into fibers. Then, they were grinded into fine powder and stirred well in $1000 \mathrm{~mL}$ of distilled water at $100^{\circ} \mathrm{C}$ for $2 \mathrm{~h}$ to remove impurities and aqueous soluble organic substances. They were then cooled to room temperature and filtered. This process was conducted twice, and the final bulk celluloses were then dried in an air oven at $70^{\circ} \mathrm{C}$ for $8 \mathrm{~h}$. Twenty grams of the pretreated biomass powder were dispersed into $\mathrm{HCOOH}$ $90 \%(1: 10 \mathrm{w} / \mathrm{v})$ solution at $100^{\circ} \mathrm{C}$ for $2 \mathrm{~h}$ by magnetic agitator in circulation system. This suspension was filtered, and the obtained residue was washed successively with pure $\mathrm{HCOOH}$ acid and warm distilled water to break the $\beta$-O-4 linkages of hemicellulose as well as dissolve the impurities remnant. To remove hemicellulose, after pretreatment with acid, samples were dissolved into PFA (a mixed solvent of formic acid, hydrogen peroxide, and distilled water with the ratio of $90: 4: 6 \% \mathrm{w} / \mathrm{w}$, respectively) and stirred well at $80^{\circ} \mathrm{C}$ for $2 \mathrm{~h}$. The suspension was then filtered and washed with formic acid $(80 \%)$ and distilled water, respectively. Finally, the fiber was bleached with a combined solution of $\mathrm{NaOH}$ and $\mathrm{H}_{2} \mathrm{O}_{2}$ $(1: 1 \mathrm{w} / \mathrm{w})$ in using a magnetic stirring circulation system at $80^{\circ} \mathrm{C}$ for $1 \mathrm{~h}$, finally filtered and rinsed several times to get rid of lignin and hemicelluloses. This bleaching process was repeated two times until the fibers became white. It has been reported that apart from improving the physical appearance of fibers, bleaching procedure also helps in improvement of mechanical properties due to the better interfacial adhesion between fibers and matrix [22]. The cellulose was then obtained after filtration and three times washing with deionized water and allowed to air dry for $48 \mathrm{~h}$.

\subsection{Preparation of Zinc Oxide/Cellulose Nanocrystal} ( $\mathrm{ZnO} / \mathrm{CNC}$ ) Nanohybrids. $\mathrm{ZnO} / \mathrm{CNC}$ nanohybrids were prepared by a one-pot synthesis route as reported in other paper [23] in which CNC with carboxyl groups was obtained to fabricate $\mathrm{Zn}(\mathrm{OH})_{2} / \mathrm{CNC}$ by simple precipitation through electrostatic interaction, and finally, $\mathrm{ZnO} / \mathrm{CNC}$ nanohybrids were achieved by thermal treatment. In our experiment, the starting cellulose $(8 \mathrm{~g})$ was added to $400 \mathrm{~mL}$ mixed acid solution of $90 \% \mathrm{C}_{6} \mathrm{H}_{8} \mathrm{O}_{7} / 10 \% \mathrm{HCl}\left(400 \mathrm{~mL}, 3 \mathrm{M} \mathrm{C}_{6} \mathrm{H}_{8} \mathrm{O}_{7}\right.$, and $6 \mathrm{M} \mathrm{HCl}$ ). The mixture was heated at $80^{\circ} \mathrm{C}$ for $6 \mathrm{~h}$ under continuously mechanical stirring, and the suspension was rapidly cooled to room temperature. The functionalized CNC and recycled acid mixtures were then separated by filtration processes, and the CNC samples were washed 3 times with deionized water by centrifugation. The centrifuged samples were left overnight by drying in an oven at $80^{\circ} \mathrm{C}$ for several hours. This CNC powders were used directly to prepare $\mathrm{ZnO} / \mathrm{CNC}$ nanohybrids by adding it to $\mathrm{Zn}\left(\mathrm{NO}_{3}\right)_{2} \cdot 6 \mathrm{H}_{2} \mathrm{O}$ solutions $(0.1 \mathrm{~mol} / \mathrm{L})$ with different weight ratios $\left(\mathrm{Zn}\left(\mathrm{NO}_{3}\right)_{2} \cdot 6\right.$ $\mathrm{H}_{2} \mathrm{O} / \mathrm{CNC}$ powder) of $0.5,1.0$, and 2.0. The $\mathrm{pH}$ values of these three samples were adjusted to 7 by using $\mathrm{NaOH}$ solution $(0.5 \mathrm{~mol} / \mathrm{L})$. Then, the mixture was heated to $80^{\circ} \mathrm{C}$, and $0.1 \mathrm{M} \mathrm{NaOH}$ solution was added dropwise to precipitate $\mathrm{Zn}^{2+}$ completely with vigorous stirring. $\mathrm{Zn}(\mathrm{OH})_{2}$ nanoparticles were obtained by simple precipitation through electrostatic adsorption between carboxylates $\left(\mathrm{COO}^{-}\right)$of $\mathrm{CNC}$ and $\mathrm{Zn}^{2+}$. The mixture was then washed repeatedly by centrifugation $(5,000 \mathrm{rpm}$ for $20 \mathrm{~min})$ with deionized water to remove remaining zinc species and by products. Finally, the samples were dried at $120^{\circ} \mathrm{C}$ for $1 \mathrm{~h}$ to transform $\mathrm{Zn}(\mathrm{OH})_{2}$ to $\mathrm{ZnO}$. In the following manuscript, the three samples were labelled 
according to the weight ratio of $\mathrm{Zn}\left(\mathrm{NO}_{3}\right)_{2} \cdot 6 \mathrm{H}_{2} \mathrm{O}$ to $\mathrm{CNC}$ powder as $\mathrm{ZnO} / \mathrm{CNC}-0.5, \mathrm{ZnO} / \mathrm{CNC}-1.0$, and $\mathrm{ZnO} / \mathrm{CNC}$ 2.0. For reference, the as-produced $\mathrm{CNC}$ suspensions were also purified by deionized water to remove the remaining cellulose hydrolysis products.

2.3. Characterization. The structure morphologies of the $\mathrm{CNC}$ and $\mathrm{ZnO} / \mathrm{CNC}$ nanohybrids were observed at room temperature by using the field-emission scanning electron microscopy (FE-SEM, S-4800; Hitachi, Japan) at acceleration voltage of $10.0 \mathrm{kV}$. Fourier-transform infrared (FT-IR) spectra of the samples were obtained by using an FT-IR spectrometer (Nicolet 6700; Thermo Fisher SCIENTIFIC, USA) using the $\mathrm{KBr}$ disc method. Disks containing $2 \mathrm{mg}$ of sample were scanned in the wavenumber range of $400-4,000 \mathrm{~cm}^{-1}$. The crystalline phase and its crystallite size of synthesized $\mathrm{CNC}$ powders and $\mathrm{ZnO} / \mathrm{CNC}$ nanohybrids were characterized by an X-ray powder diffractometer (XRD, D2 PHARSER; Bruker) with monochromatic $\mathrm{Cu} \mathrm{K}_{\mathrm{a}}$ radiation at $\lambda=1.54056 \AA$ in the $2 \theta$ range of $10-80^{\circ}$ at scan rate of $0.02^{\circ} / \mathrm{min}$. The $\mathrm{X}$-ray generator tension and current were $40 \mathrm{kV}$ and $30 \mathrm{~mA}$, respectively. The TGA experiment was conducted using a thermogravimetric analyzer (TA Instruments TGA Q500). The samples (15-20 mg) were heated at a rate of $10^{\circ} \mathrm{C} / \mathrm{min}$ from room temperature to $700^{\circ} \mathrm{C}$ under a nitrogen flow rate of $30 \mathrm{~mL} \cdot \mathrm{min}^{-1}$. The specific surface area of our materials was measured via the nitrogen adsorption-desorption experiments on a NOVA 1000e analyzer (Quantachrome Instruments). The band gap energy (Eg) values of nanohybrids were determined from room temperature UV-visible diffuse reflectance spectra (DRS) using a Perkin-Elmer Lambda 850 Spectrophotometer equipped with a $15 \mathrm{~cm}$ diameter integrating sphere bearing the holder in the bottom horizontal position.

2.4. Adsorption and Photocatalytic Evaluation. The adsorption/photocatalytic efficiency of the samples was investigated by monitoring the removal of $\mathrm{MB}$ dye as a model compound. $40 \mathrm{mg}$ of $\mathrm{ZnO} / \mathrm{CNC}$ powders were dispersed into $50 \mathrm{~mL}$ of $\mathrm{MB}$ aqueous solution $\left(10.0 \times 10^{-5} \mathrm{M}\right)$. In order to determine adsorption equilibrium, the suspensions were stirred in dark for $2.5 \mathrm{~h}$ at $200 \mathrm{rpm}$. The saturation adsorption was obtained after $15 \mathrm{~min}$. Continuously, the suspensions were irradiated by UVC lamp (15 W Osram Germicidal, $\lambda=234 \mathrm{~nm}$ ) to activate the photocatalytic process. A certain amount of solution $(\sim 3 \mathrm{~mL})$ was taken out at given time intervals $(30 \mathrm{~min})$, and a UV-vis spectrophotometer (model V-670, Jasco, Japan) was used to measure the absorbance of samples. The removal percentages $(R)$ of $\mathrm{MB}$, indicating adsorption ability, were calculated by using

$$
R=\frac{C_{0}-C_{t}}{C_{0}} \times 100 \%,
$$

where $C_{o}$ and $C_{t}$ are the initial concentration and concentration of $\mathrm{MB}$ dye after the adsorption equilibrium without UVC irradiation, respectively. The degradation rate was calculated as follows:

$$
\text { Degradation rate }(\%)=\frac{C_{o}^{s}-C_{t}}{C_{t}} \times 100 \text {, }
$$

where $C_{o}$ represents the initial concentration of $\mathrm{MB}$ dye (after the absorption equilibrium) and $C_{t}$ is the final concentration after illumination by UVC for $t$ time.

\section{Results and Discussion}

\subsection{Structure, Morphology, and Surface Area of CNC and $\mathrm{ZnO}$ CNC Nanohybrids}

3.1.1. Structure. The XRD diffractograms of every NFT treatment stage and the $\mathrm{CNC}, \mathrm{ZnO}$, and $\mathrm{ZnO} / \mathrm{CNC}-0.5$ nanohybrids are shown in Figure 1. The results present their CNC monoclinic structure. The (101), (002), and (040) lattice planes were observed at $2 \theta=16.15,22.65$, and $34.88^{\circ}$, respectively. These peaks correspond to polymorph of cellulose I (indexed to the database of ID number COD 4114994) [24]. XRD profiles of the cellulosic products obtained at each stage were analyzed to monitor the evolution of the percentage crystalline index (CrI) of nanocellulose. The physical and mechanical properties of cellulose are influenced by its crystalline structure. CrI is one important parameter of the crystal structure. The pretreatment of cellulose fibers increases their CrI meaning to the increasing of ratio of crystalline and amorphous region and surface roughness as well. This made it easy for the adhesion of $\mathrm{ZnO}$ onto the cellulose matrix. From XRD analysis, the CrI of cellulose and pretreated fibers was calculated in using the amorphous subtraction method described by Equation (3) [25]:

$$
\operatorname{CrI}(\%)=\frac{I_{002}-I_{\mathrm{am}}}{I_{002}} \times 100,
$$

where $I_{002}$ is the maximum diffraction intensity of the characteristic peak (002) at around $22-23^{\circ}$ and $I_{\mathrm{am}}$ is the diffraction intensity attributed to amorphous cellulose, which is the valley between peaks (101) and (002). Treatment of the fibers increased their \% CrI. The calculated \% CrI were 57.1, 62.3, 78.9 , and $84.5 \%$ for biomass obtained after acid, PFA, bleaching treatments, and the final acid hydrolysis, respectively. From these results, it can be deduced that each treatment step affected the crystallinity of the materials. The CrI was found to have increased by $26.9 \%$ after the removal of lignin and hemicellulose. The increasing \% CrI indicates an improvement of the cellulose crystallinity.

The XRD patterns of $\mathrm{ZnO}$ with high intensity of the peaks revealed the single-phase crystalline nature of the synthesized $\mathrm{ZnO}$ nanostructures. The characteristic peaks correspond to the (100), (002), (101), (102), (110), (103), (200), (201), and (112) planes of $\mathrm{ZnO}$ were observed at $2 \theta=31.89$, $34.60,36.39,47.62,56.67,62.97,66.47,68.11$, and $69.17^{\circ}$, respectively. This result is similar to those reported previously $[16,17]$ and are consistent with the database of ID number COD 1011258 with a wurtzite hexagonal crystallographic lattice of $\mathrm{ZnO}$. The $\mathrm{ZnO} / \mathrm{CNC}-0.5 \mathrm{XRD}$ profile displays two-phase structures corresponding to cellulose $(*)$ and $\mathrm{ZnO}(\#)$ as indicated in Figure 1(b). In addition, the XRD 


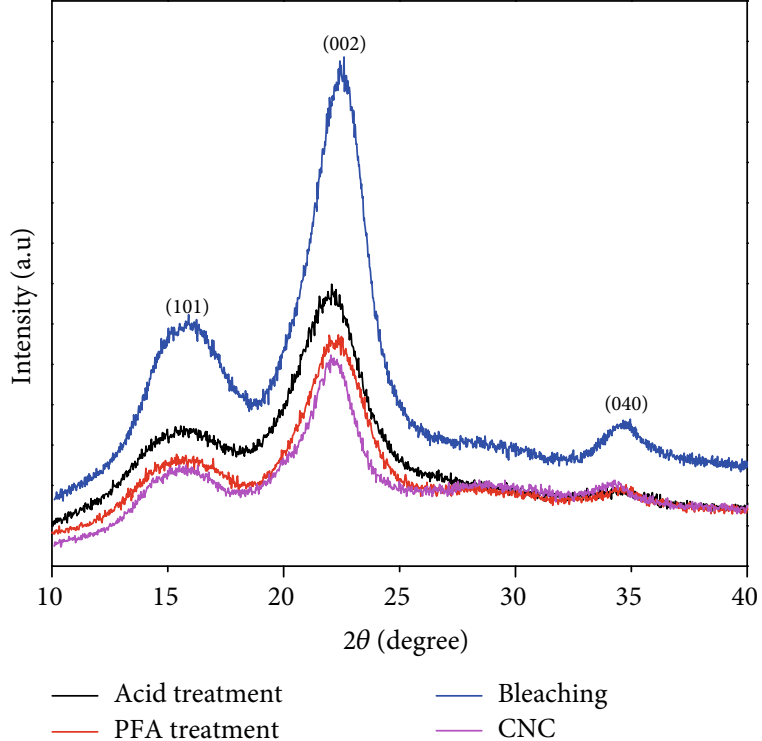

(a)

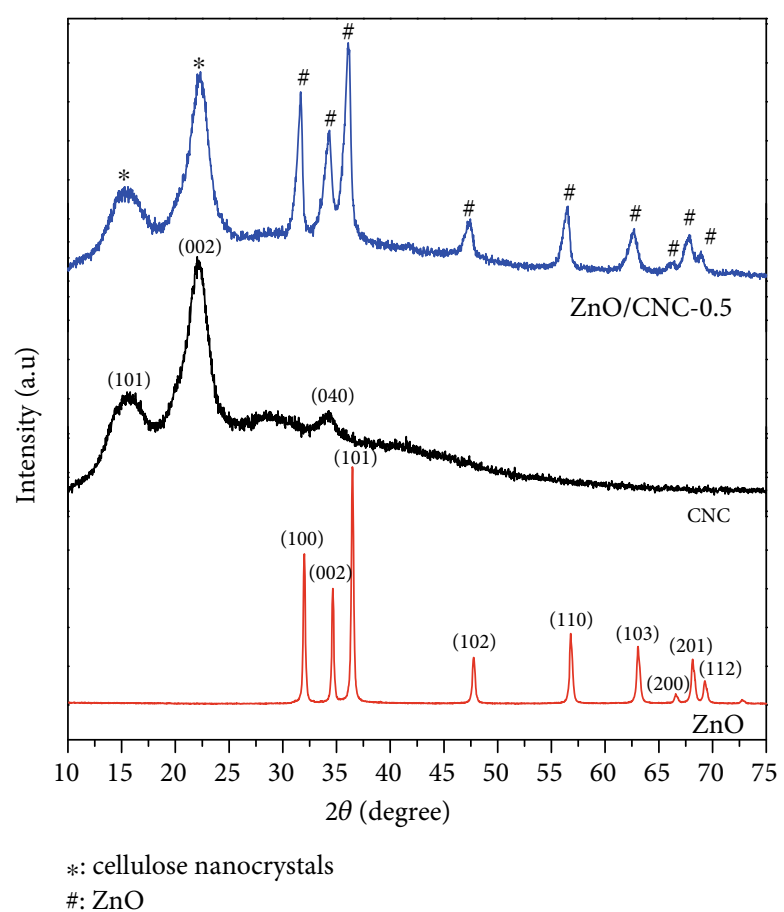

(b)

FIGURE 1: XRD patterns of different treatment stages by acid, PFA, bleaching, and the final acid hydrolysis for NFT (a) and CNC, ZnO, and $\mathrm{ZnO} / \mathrm{CNC}-0.5$ nanohybrids (b).

diagrams of $\mathrm{ZnO} / \mathrm{CNC}-1.0$ and $\mathrm{ZnO} / \mathrm{CNC}-2.0$ nanohybrids were similar to that of $\mathrm{ZnO} / \mathrm{CNC}-0.5$ in Figure 2, indicating the successful synthesis of this material by the facile onestep route. It can be deduced from these profiles that the presence of well crystalline $\mathrm{ZnO}$ has not altered the crystal structure of the cellulose matrix.

The average crystallite size $(D)$ of cellulose, pure $\mathrm{ZnO}$, and $\mathrm{ZnO}$ in the nanohybrids was calculated from XRD analysis using Equation (4): the Debye-Scherrer formula:

$$
D=\frac{0.9 \lambda}{\beta \cos \theta},
$$

where $D$ is the crystallite size corresponding to the $(h k l)$ plane, $\lambda$ is the wavelength of copper $K_{\alpha}$ X-ray radiation $(1.5406 \AA), \beta$ is the observed angular width at half maximum intensity (FWHM), and $\theta$ is the Bragg diffraction angle measured in radians. In this work, the most intense diffraction lines ((100), (002), and (101)) were selected to calculate the average size of $\mathrm{ZnO}$ crystals. The lattice parameters $a, b$, and $c$, which are related to the interplanar distance $(d)$ and Miller indices $h, k$, and $l$, were calculated for pure $\mathrm{ZnO}$ and $\mathrm{ZnO}$ in the nanohybrids using Equation (5) to determine the influence of cellulose nanocrystals

$$
\frac{1}{d^{2}}=\frac{4}{3}\left(\frac{h^{2}+h k+l^{2}}{a^{2}}\right)+\frac{l^{2}}{c^{2}} .
$$

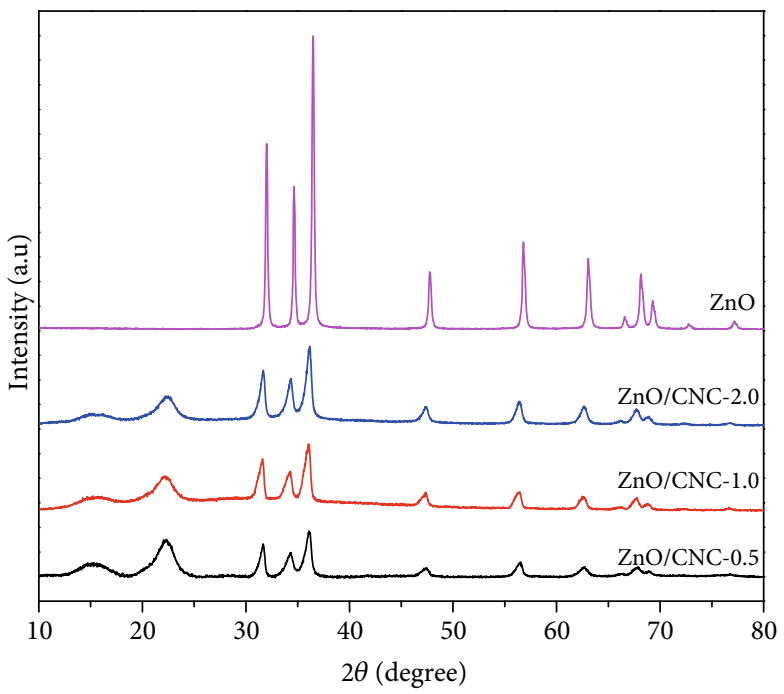

Figure 2: XRD patterns of $\mathrm{ZnO}$ and $\mathrm{ZnO} / \mathrm{CNC}$ nanohybrids.

The calculated lattice parameters are reported in Table 1. As observed in literature [22], compared to pure $\mathrm{ZnO}$, the crystallite size of $\mathrm{ZnO}$ in the nanohybrids is much smaller, and there is a slight increase in the value of lattice parameters. According to Sharma et al. [26], the increase in the value of lattice parameters indicates the stretching of unit cells due to adsorption of polymer molecular chains on the surface of $\mathrm{ZnO}$ nanostructures.

The chemical structure of $\mathrm{CNC}$ and $\mathrm{ZnO} / \mathrm{CNC}$ nanohybrids was analyzed using FTIR spectroscopy as shown in Figure 3. Similar characteristic bands corresponding to CNC 
TABLE 1: Structural parameters of $\mathrm{ZnO}$ nanocrystals.

\begin{tabular}{|c|c|c|c|c|c|}
\hline \multirow{2}{*}{ Sample } & \multirow{2}{*}{ Crystallite size $(\mathrm{nm})$} & \multirow{2}{*}{ Interplanar distance $(\mathrm{d})(\mathrm{nm})$} & \multicolumn{2}{|c|}{ Lattice parameters } & \multirow{2}{*}{ Lattice constant $c / a$} \\
\hline & & & $a=b(\mathrm{~nm})$ & $c(\mathrm{~nm})$ & \\
\hline $\mathrm{ZnO}$ (pure) & 32.8 & 0.2461 & 0.5323 & 0.2833 & 0.5323 \\
\hline $\mathrm{ZnO} / \mathrm{CNC}-0.5$ & 6.8 & 0.2489 & 0.5359 & 0.2872 & 0.5359 \\
\hline $\mathrm{ZnO} / \mathrm{CNC}-1.0$ & 9.1 & 0.2498 & 0.5369 & 0.2883 & 0.5369 \\
\hline $\mathrm{ZnO} / \mathrm{CNC}-2.0$ & 10.3 & 0.2489 & 0.5359 & 0.2872 & 0.5359 \\
\hline
\end{tabular}

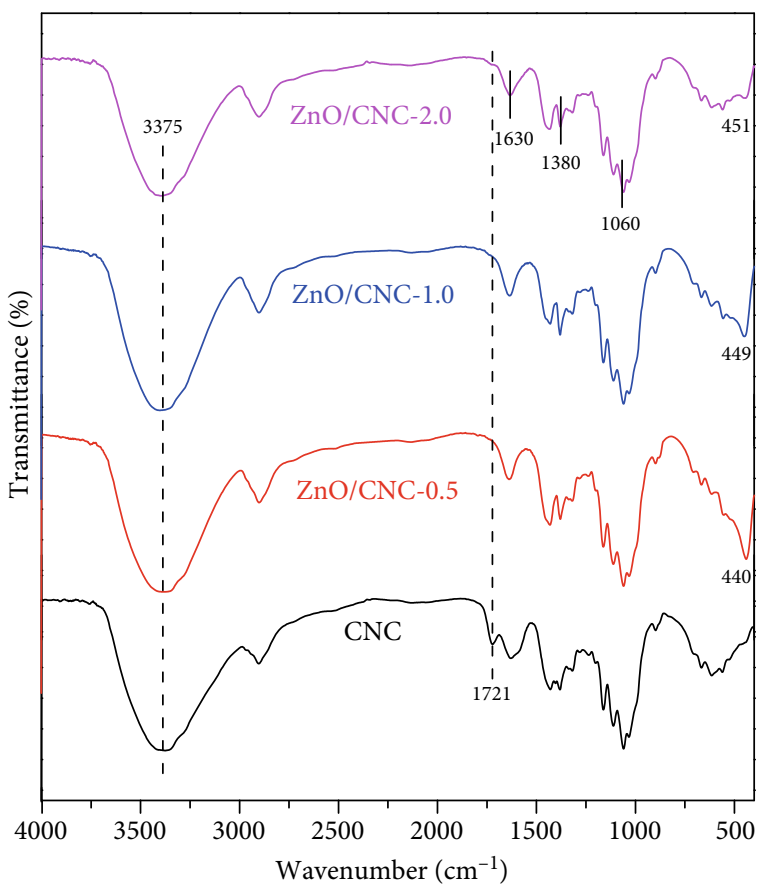

FIGURE 3: FT-IR spectra of CNC and $\mathrm{ZnO} / \mathrm{CNC}$ nanohybrids.

were observed for the $\mathrm{ZnO} / \mathrm{CNC}$ nanohybrids at 3,375 and $1,380 \mathrm{~cm}^{-1}$, which can be related to stretching and bending vibrations of hydroxyl groups, respectively. The peaks at around 1,630 and $1,060 \mathrm{~cm}^{-1}$ can be attributed to $\mathrm{O}-\mathrm{H}$ bending of absorbed water and $\mathrm{C}-\mathrm{O}-\mathrm{C}$ stretching of pyranose and glucose ring skeletal vibration, respectively.

Compared to $\mathrm{CNC}$, the nanocrystalline character of the obtained $\mathrm{ZnO}$ nanoparticles in the nanohybrids was confirmed by a new absorption band at $440 \mathrm{~cm}^{-1}$, assigned to $\mathrm{Zn}-\mathrm{O}$ stretching vibration. With increasing concentration of $\mathrm{Zn}^{2+}$ ions, a slight shift of the $\mathrm{Zn}-\mathrm{O}$ stretching bands to higher wavenumber was observed due to the lattice parameter of the $\mathrm{ZnO}$ nanoparticles. Besides, in comparison to $\mathrm{CNC}$, the band intensity of $\mathrm{C}=\mathrm{O}$ stretching vibration $\left(1,721 \mathrm{~cm}^{-1}\right)$ decreased, which was ascribed to strong interactions between oxygen atoms of carboxyl groups on the surface of the CNC and $\mathrm{ZnO}$ nanoparticles.

The DRS curves of the $\mathrm{ZnO}$ and $\mathrm{ZnO} / \mathrm{CNC}$ nanohybrids are presented in Figure 4(a). The figure shows the strong absorption edge around $400 \mathrm{~nm}$ for all the $\mathrm{ZnO} / \mathrm{CNC}$ nanohybrids. Based on the Tauc plot in Figure 4(b), the band gap values of them range about 3.1-3.2 eV. This result implies that these materials could absorb the irradiation light at wavelength of $254 \mathrm{~nm}$ in photocatalysis process.
3.1.2. Morphology and Surface Area. FE-SEM images of the $\mathrm{CNC}$ and $\mathrm{ZnO} / \mathrm{CNC}$ nanohybrids are shown in Figure 5. It can be observed that the CNC appeared as rod-like monocrystals of $20 \mathrm{~nm}$ in diameter and $240-300 \mathrm{~nm}$ in length. After the precipitation process between $\mathrm{CNC}$ and $\mathrm{Zn}^{2+}$ ions, well-dispersed $\mathrm{ZnO}$ nanoparticles with average diameter of $50.2 \mathrm{~nm}$ and narrow size distribution $(15-85 \mathrm{~nm})$ were anchored on the surface of the CNC (ZnO/CNC-1.0). With increasing concentration of $\mathrm{Zn}^{2+}$ ions, the average diameter of the $\mathrm{ZnO}$ nanoparticles increased to $126.6 \mathrm{~nm}$ in $\mathrm{ZnO} / \mathrm{CNC}-2.0$.

The increase of $\mathrm{Zn}^{2+}$ ion concentration on the surface of the CNC enhances more $\mathrm{Zn}^{2+}$ ions anchored on CNC. This leads to an increase of $\mathrm{ZnO}$ particles not only in number but also in size on the surface of the CNC.

The formation of $\mathrm{ZnO}$ on $\mathrm{CNC}$ can be explained as follows. During the CNC hydrolysis, the hydronium ions $\left(\mathrm{H}_{3} \mathrm{O}^{+}\right)$from $\mathrm{HCl}$ catalysts were used to catalyze the esterification of hydroxyl groups on the exposed cellulose chains with carboxyl groups of citric acid $\left(\mathrm{C}_{6} \mathrm{H}_{8} \mathrm{O}_{7}\right)$. This reaction leads to the existence of carboxyl groups $(-\mathrm{COOH})$ on the surface of citrate $\mathrm{CNC}$. Then, $\mathrm{Zn}\left(\mathrm{NO}_{3}\right)_{2} \cdot 6 \mathrm{H}_{2} \mathrm{O}$ solutions were added, and $\mathrm{Zn}^{2+}$ ions would be adsorbed on $\mathrm{COO}^{-}$negative site $\mathrm{CNC}$ surface due to the strong electrostatic interactions of these ions. When the $\mathrm{Zn}^{2+}$ concentration was low, the concentration of the carboxylate anion $\left(\mathrm{COO}^{-}\right)$from carboxyl groups on the CNC template was high. All $\mathrm{Zn}^{2+}$ ions were significantly located at these negative site, bonded to the anionic $\mathrm{OH}^{-}$to form the monomer zinc hydroxide $\mathrm{Zn}(\mathrm{OH})_{2}$ and two adjacent $\mathrm{Zn}(\mathrm{OH})_{2}$ dehydrated to form zinc oxide $(\mathrm{ZnO})$ particles. As the result, the growth of $\mathrm{ZnO}$ crystals on CNC surface deduces an increase of the surface area. Figure 6 shows the nitrogen adsorption-desorption isotherms and the values of specific surface areas $\left(S_{\mathrm{BET}}\right)$ of samples with different concentrations of $\mathrm{ZnO}$.

At light zinc-precursor $\mathrm{Zn}\left(\mathrm{NO}_{3}\right)_{2} \cdot 6 \mathrm{H}_{2} \mathrm{O}$, the synthesized nanohybrids showed an increased surface area compared with CNC. The $S_{\mathrm{BET}}$ values of the $\mathrm{CNC}, \mathrm{ZnO} / \mathrm{CNC}-0.5$, and $\mathrm{ZnO} / \mathrm{CNC}-1.0$ were $69.1,73.1$, and $74.8 \mathrm{~m}^{2} \cdot \mathrm{g}^{-1}$, respectively.

As the $\mathrm{Zn}^{2+}$ concentration increased, there are a large amount of $\mathrm{Zn}(\mathrm{OH})_{2}$ monomers formed in bulk solution, not anchored on the surface of the CNC. After that, the new bonds are produced after two $\mathrm{Zn}(\mathrm{OH})_{2}$ monomer dehydration to assemble along a certain orientation direction. The $\mathrm{ZnO}$ crystals grew continuously and eventually formed a sheet-like structure with the average diameter of the $\mathrm{ZnO}$ nanoparticles increased to $126.6 \mathrm{~nm}$ diameter, as show in FESEM image of $\mathrm{ZnO} / \mathrm{CNC}-2.0$ nanohybrid. The assembly of $\mathrm{ZnO}$ nanoparticles into two-dimensional sheet-like structure of $\mathrm{CNC}$ 


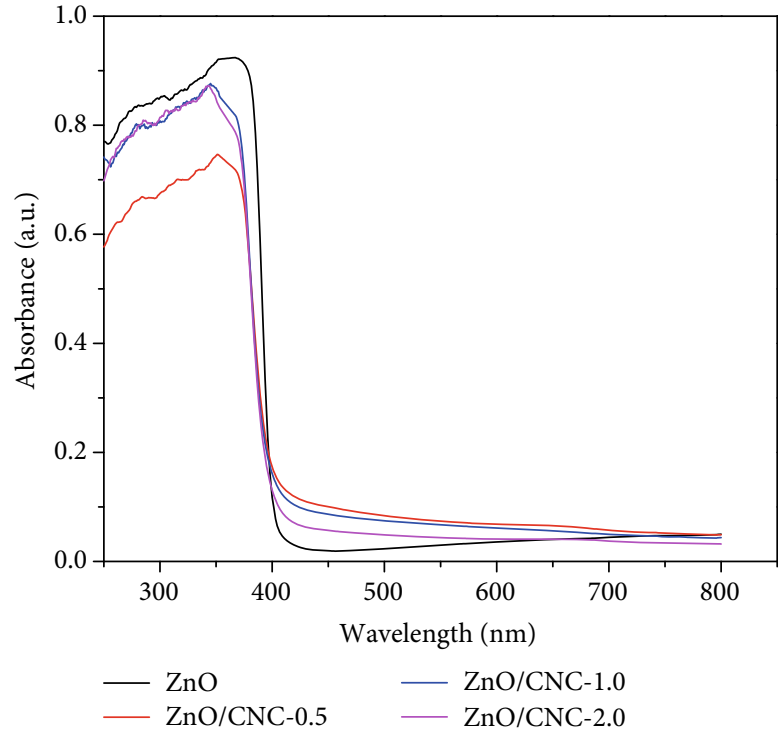

(a)

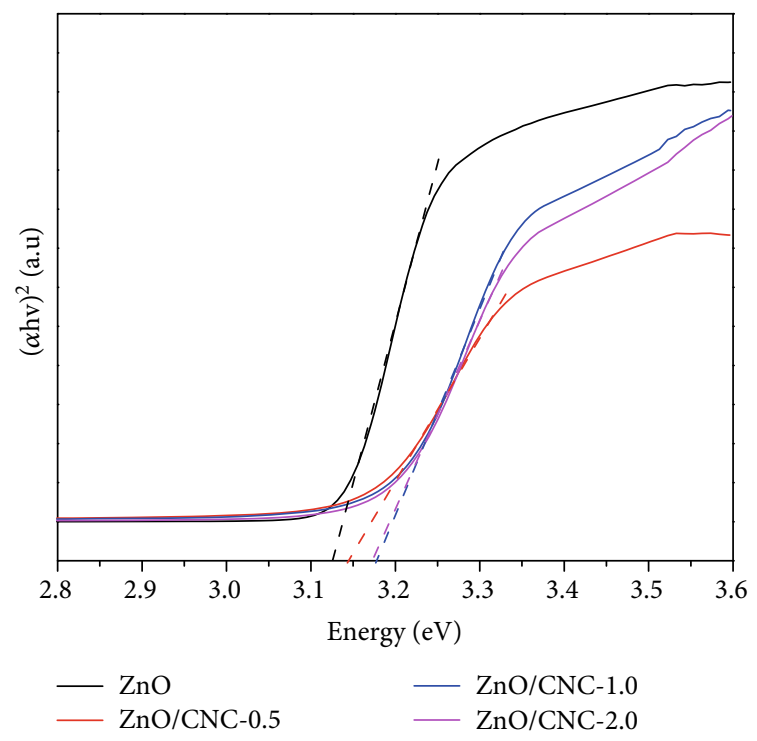

(b)

Figure 4: UV-vis diffuse reflectance spectra (a) and band gap determination from Tauc plot (b) of $\mathrm{ZnO}$ and nanohybrids.
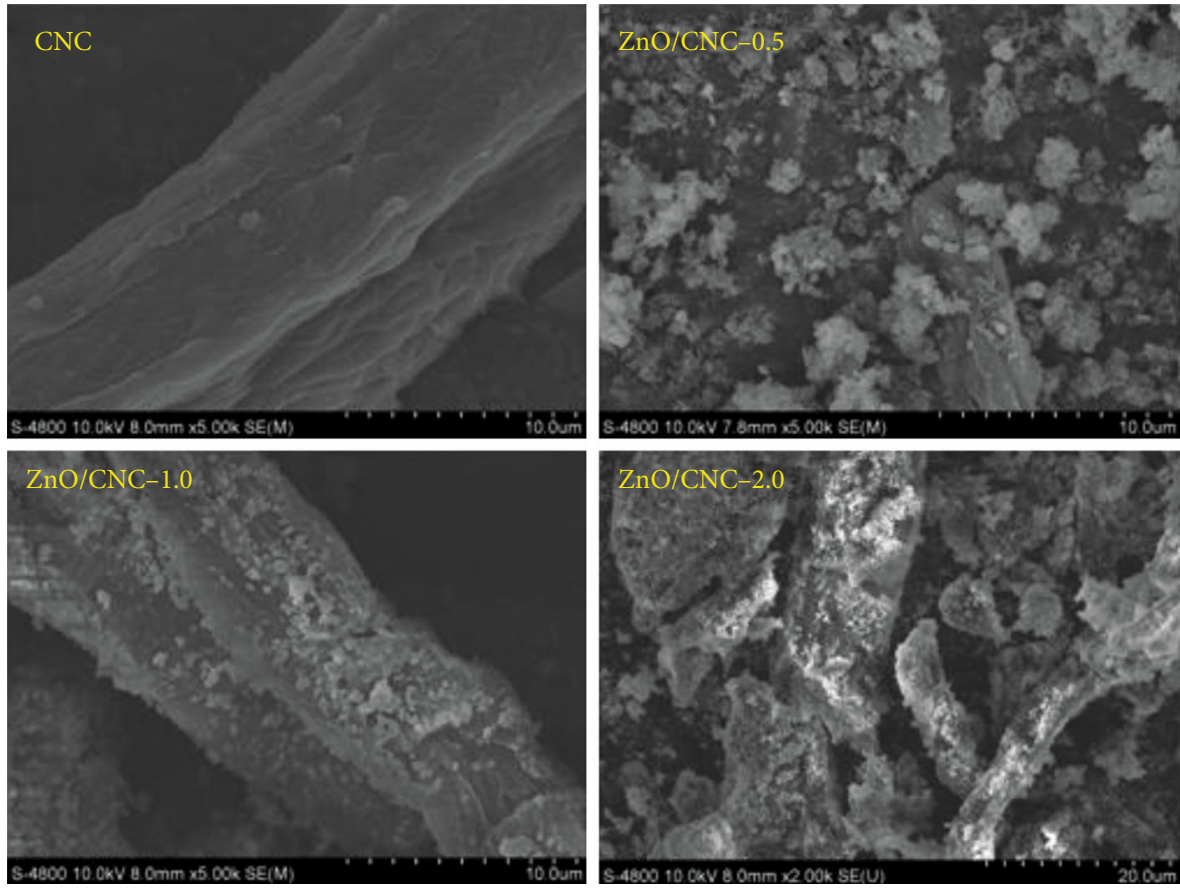

FIGURE 5: FE-SEM images of $\mathrm{CNC}$ and $\mathrm{ZnO} / \mathrm{CNC}$ nanohybrids.

template led to a decrease of surface area as indicated in BET results of $\mathrm{ZnO} / \mathrm{CNC}-2.0$ nanohybrid (Figure 6).

\subsection{Thermal Properties of CNC and ZnO/CNC Nanohybrids.} Thermogravimetric analysis (TGA) has been used to characterize the thermal behavior of the $\mathrm{CNC}$ and $\mathrm{ZnO} / \mathrm{CNC}$ nanohybrids. The thermal degradation onset temperature $\left(T_{0}\right)$, maximum degradation temperature $\left(T_{\max }\right)$, and apparent activation energy $\left(E_{\mathrm{a}}\right)$ are listed in Table 2.

Figure 7 shows the thermal degradation of $\mathrm{CNC}$ and $\mathrm{ZnO} / \mathrm{CNC}$ nanohybrids elaborated by the one main step of maximum degradation temperature. It shows that the CNC has the lowest thermal stability (Figure $7(\mathrm{a})$ ). The $T_{\mathrm{o}}$ and $T_{\max }$ values of the CNC were about 293.3 and $376.7^{\circ} \mathrm{C}$, respectively. Thermal degradation of cellulose involves depolymerization, dehydration, and decomposition of glycosyl units followed by formation of a charred residue. The result indicates that inorganic nanomaterials can significantly improve the thermal stability of polymer matrix. In comparison to CNC, the thermal degradation curves of the $\mathrm{ZnO} / \mathrm{CNC}$ nanohybrids with a single degradation peak have shifted to higher temperature (Figure $7(\mathrm{~b})$ ). Furthermore, the $T_{\mathrm{o}}$ and 


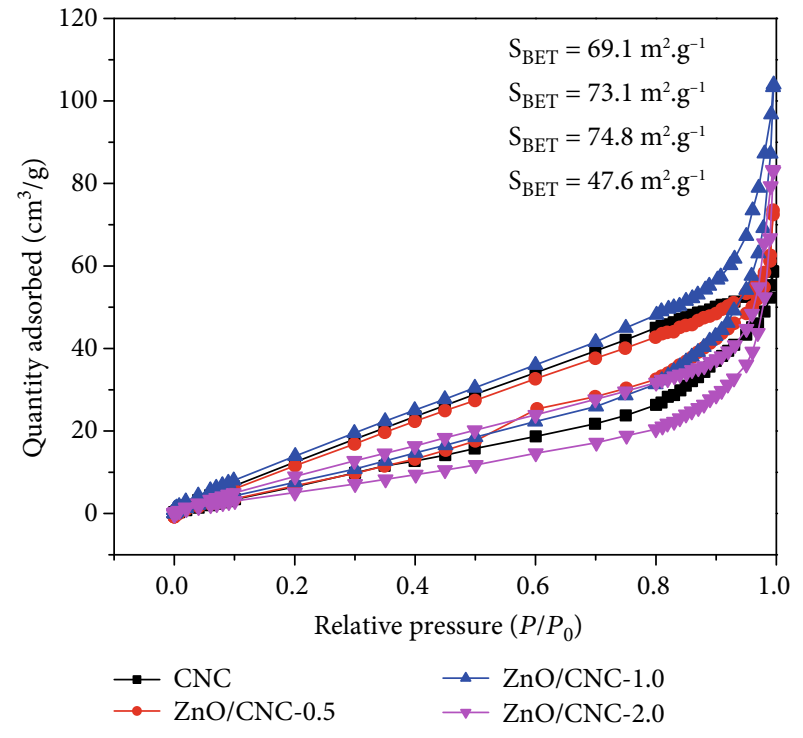

FIGURE 6: Nitrogen adsorption-desorption isotherm curves for $\mathrm{CNC}$, $\mathrm{ZnO} / \mathrm{CNC}-0.5$, $\mathrm{ZnO} / \mathrm{CNC}-1.0$, and $\mathrm{ZnO} / \mathrm{CNC}-2.0$ nanohybrids.

TABle 2: $T_{\mathrm{o}}, T_{\max }$, and $E_{\mathrm{a}}$ parameters for $\mathrm{CNC}$ and $\mathrm{ZnO} / \mathrm{CNC}$ nanohybrids.

\begin{tabular}{lccc}
\hline Sample & $T_{\mathrm{o}}\left({ }^{\circ} \mathrm{C}\right)^{\mathrm{a}}$ & $T_{\max }\left({ }^{\circ} \mathrm{C}\right)^{\mathrm{a}}$ & $E_{\mathrm{a}}\left(\mathrm{kJ} \cdot \mathrm{Mol}^{-1}\right)^{\mathrm{b}}$ \\
\hline CNC & 293.3 & 376.7 & 128.7 \\
ZnO/CNC-0.5 & 327.7 & 367.7 & 117.7 \\
ZnO/CNC-1.0 & 329.5 & 373.6 & 137.7 \\
ZnO/CNC-2.0 & 321.6 & 357.4 & 176.0 \\
\hline
\end{tabular}

${ }^{\mathrm{a}} T_{\mathrm{o}}$ and $T_{\max }$ calculated from TGA curves. ${ }^{\mathrm{b}} E_{\mathrm{a}}$ calculated by the Horowitz and Metzger method.

$T_{\max }$ values increased to 327.7 and $367.7^{\circ} \mathrm{C}$ for $\mathrm{ZnO} / \mathrm{CNC}-0.5$, 329.5 and $373.6^{\circ} \mathrm{C}$ for $\mathrm{ZnO} / \mathrm{CNC}-1.0$, and 321.6 and $357.4^{\circ} \mathrm{C}$ for $\mathrm{ZnO} / \mathrm{CNC}-2.0$. In particular, $\mathrm{ZnO} / \mathrm{CNC}-1.0$ showed the best thermal stability, with the increase of $T_{\mathrm{o}}\left(36.2^{\circ} \mathrm{C}\right)$ as compared to neat CNC. This was ascribed to the stronger interactions between oxygen atoms of the $\mathrm{CNC}$ and $\mathrm{ZnO}$ nanoparticles, thus providing a thermal barrier for the cellulose skeleton. Besides, there was no further decomposition of $\mathrm{ZnO}$ nanoparticles after cellulose degradation, whereas an increase in the char fraction was observed for the $\mathrm{ZnO} / \mathrm{CNC}$ nanohybrids (Figure 7(a)). This indicates that thermally stable inorganic $\mathrm{ZnO}$ nanoparticles can act as a barrier flame retardant for the cellulose skeleton based on heat absorbance, resulting the higher degradation temperature and increased weight residue.

The apparent activation energy $\left(E_{\mathrm{a}}\right)$, corresponding to interaction between $\mathrm{CNC}$ and $\mathrm{ZnO}$ nanoparticles, was calculated from the TGA data by using the Horowitz and Metzger method [27] as follows:

$$
\ln \left[\ln \left(\frac{W_{o}}{W_{T}}\right)\right]=\frac{E_{\mathrm{a}} \theta}{R T_{S}^{2}}
$$

where $W_{o}$ is the initial sample weight, $W_{T}$ is the residual sample weight at temperature $T, T_{S}$ is the temperature determined at $36.79 \%$ weight loss, $\theta$ is $T-T_{\mathrm{S}}$, and $R$ is the gas constant.

Figure 8 shows the plots of $\ln \left[\ln \left(W_{o} / W_{T}\right)\right]$ versus $\theta$ for the main stage of the thermal degradation of the CNC and $\mathrm{ZnO} / \mathrm{CNC}$, where $E_{\mathrm{a}}$ can be calculated from the slopes of the fit lines, and the results are listed in Table 2. In general, with the higher $E_{\mathrm{a}}$ value, the faster degradation rate occurs [27]. Table 2 illustrates that $\mathrm{ZnO} / \mathrm{CNC}-2.0$ showed the highest $E_{\mathrm{a}}$ value comparing to that of $\mathrm{CNC}$ and the other nanohybrids. Based on above results, this can be seen that the addition of $\mathrm{ZnO}$ nanoparticles to $\mathrm{CNC}$ matrix may lead to the degradation behavior of CNC in two opposite ways. On the one hand, during degradation of $\mathrm{CNC}, \mathrm{ZnO}$ nanoparticles enhance the thermal stability of materials, so that the onset degradation temperature of the $\mathrm{CNC}$ gets higher, which is the factor resulting in increasing degradation rate of CNC. On the other hand, having strong interaction between $\mathrm{ZnO}$ nanoparticles with carboxyl groups of $\mathrm{CNC}$, the thermally stable $\mathrm{ZnO}$ nanoparticles, as a flame retardant, will cover the surface of $\mathrm{CNC}$ and increase the $\mathrm{CNC}$ thermal degradation temperature.

\subsection{Adsorption and Photocatalytic Properties}

3.3.1. Adsorption. Because CNC surface has negative charges originating from its abundant carboxyl groups, the cationic $\mathrm{MB}$ molecules are adsorbed on the anionic CNC in the mixture through electrostatic interactions. This is the reason why the CNC has high adsorption ability in the dark. The $\mathrm{MB}$ adsorption results in Figure 9 show a comparison of dye removal ability of $\mathrm{CNC}$ and $\mathrm{ZnO} / \mathrm{CNC}$ nanohybrids. The dye removal ability of $40.22 \%$ and $28.15 \%$ for $\mathrm{ZnO} / \mathrm{CNC}-1.0$ and $\mathrm{ZnO} / \mathrm{CNC}-2.0$, respectively, was lower than that of CNC. Meanwhile, $\mathrm{ZnO} / \mathrm{CNC}-0.5$ gave the best adsorption of dye removal (73.62\%), which is higher than that of CNC. At the same time, the dye removal ability of the nanohybrids decreased with the increase of $\mathrm{ZnO}$, indicating the more $\mathrm{ZnO}$ contents on $\mathrm{CNC}$ and the weaker dye absorption ability. It can be explained that since the low content of $\mathrm{ZnO}$ in $\mathrm{ZnO} / \mathrm{CNC}-0.5$ will make the $\mathrm{CNC}$ surface more roughness, creating the high specific surface area of the material leads to the enhancement of $\mathrm{MB}$ adsorption ability $(73.62 \%)$. With the light increase of $\mathrm{ZnO}$ content in $\mathrm{ZnO} / \mathrm{CNC}-1.0$ and $\mathrm{ZnO} / \mathrm{CNC}-2.0$ samples, the nanoparticles were found to be well dispersed and cover the CNC surface and effect negatively the adsorption ability $(40.22 \%$ and $28.15 \%$ ) by hindering the interaction between $\mathrm{MB}$ and CNC carboxyl groups.

3.3.2. Photocatalyst. The results for the photocatalytic activity are shown in Figure 10. It can be seen that the $\mathrm{ZnO} / \mathrm{CNC}$ nanohybrids possessed photocatalytic activity to decompose the dye under UV irradiation. If there was no presence of $\mathrm{ZnO}$, no remarkable change in $\mathrm{UV}$ absorption band of $\mathrm{MB}$ during $1.0 \mathrm{~h}$ of UV irradiation was observed and then after $2.5 \mathrm{~h}$ UV exposure, only $2 \%$ degradation of MB has occurred. As shown in Figure 10, under UV irradiation, about 95\% of 


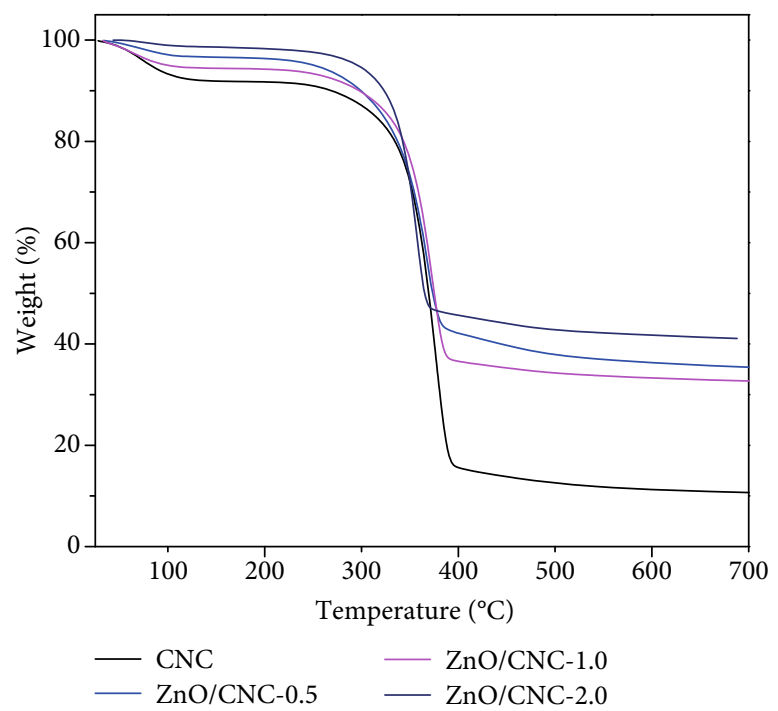

(a)

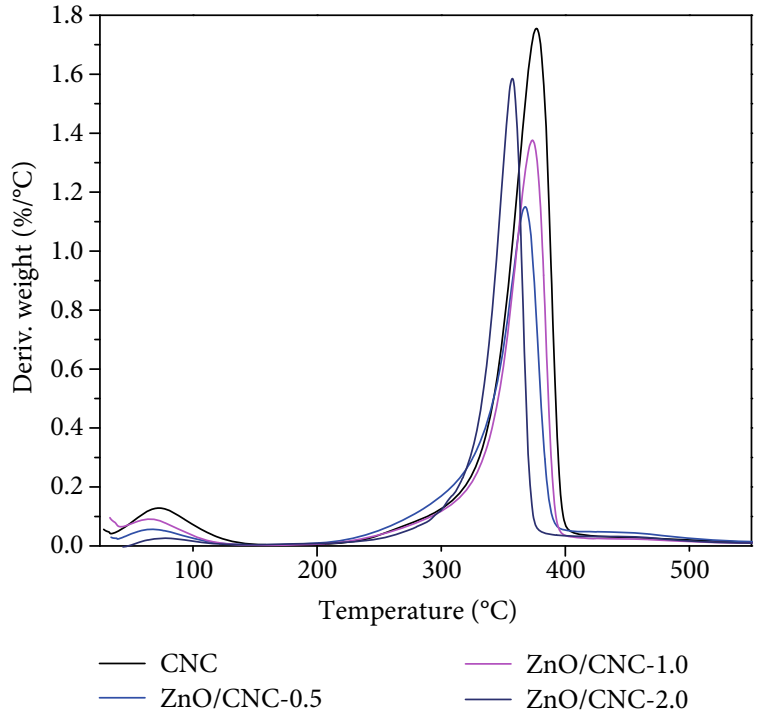

(b)

FIgURe 7: TGA (a) and differential thermogravimetry (DTG) (b) curves for CNC and ZnO/CNC nanohybrids.

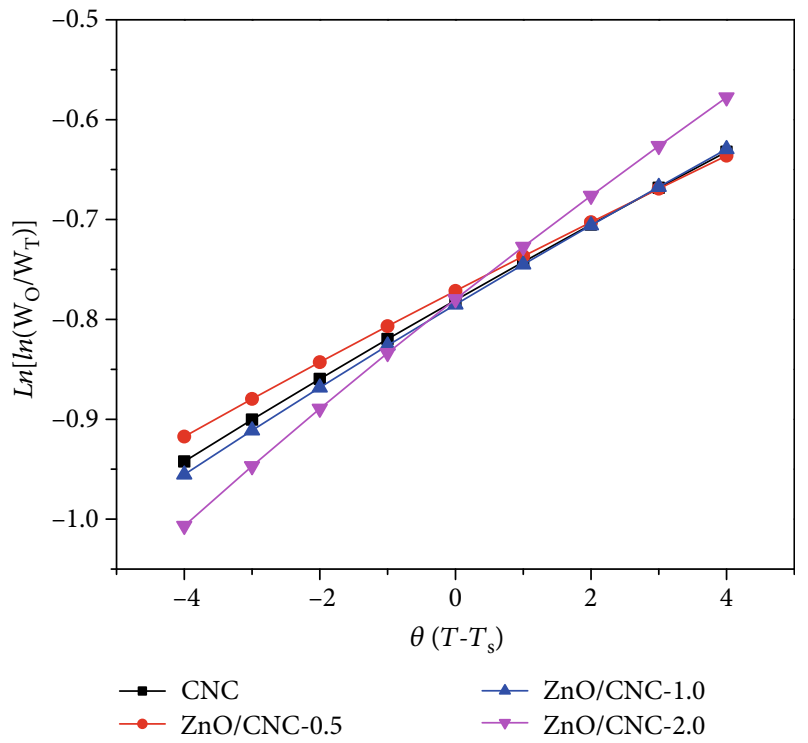

Figure 8: Plot of $\ln \left[\ln \left(W_{o} / W_{T}\right)\right]$ versus $\theta$ for the main stage of thermal degradation of $\mathrm{CNC}$ and $\mathrm{ZnO} / \mathrm{CNC}$ nanohybrids.

the $\mathrm{MB}$ dye was decomposed fast after irradiation during $150 \mathrm{~min}$ in $\mathrm{ZnO} / \mathrm{CNC}-1.0$ nanohybrid. This observation indicates that the $\mathrm{ZnO} / \mathrm{CNC}-1.0$ nanohybrid, having well dispersion at small size of $\mathrm{ZnO}$ nanoparticles on the $\mathrm{CNC}$ surface, possessed high photocatalytic activity due to the strong electronic interaction between the $\mathrm{CNC}$ and $\mathrm{ZnO}$ nanoparticles. Photocatalysis occurs as $\mathrm{ZnO}$ photocatalyst is irradiated by light with energy larger than its band gap energy. After absorbing excited energy, photogenerated electron-hole pairs would be produced and migrated to the surface of $\mathrm{ZnO}$ nanoparticles (Equation (7)). Then, these $\mathrm{e}^{-}$and $\mathrm{h}^{+}$can react with $\mathrm{O}_{2}$ and $\mathrm{H}_{2} \mathrm{O}$ absorbed on its surface to generate active radical $\mathrm{OH}^{-}$(Equation (8)) and $\mathrm{O}_{2}{ }^{-}$(Equation

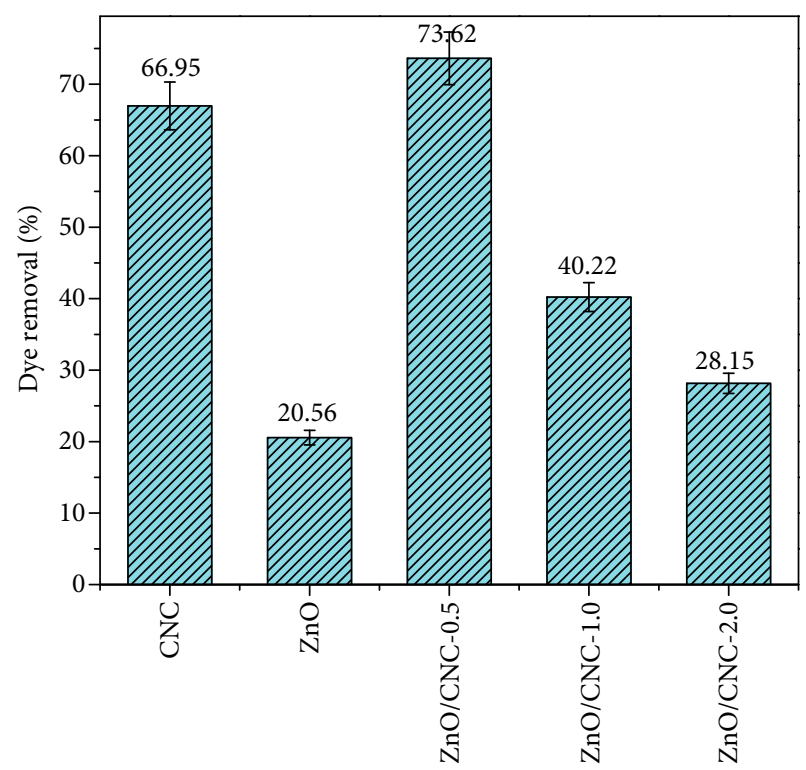

Figure 9: Dye removal of $\mathrm{CNC}$ and $\mathrm{ZnO} / \mathrm{CNC}$ hybrids.

(9)), which could participate in dye degradation by direct oxidation $[11,22,28]$.

$$
\begin{aligned}
\mathrm{ZnO}+\mathrm{h} v & \longrightarrow \mathrm{ZnO}\left(\mathrm{e}_{\text {sur }}^{-}+\mathrm{h}_{\text {sur }}^{+}\right) \\
\mathrm{h}^{+}+\mathrm{H}_{2} \mathrm{O}\left(\mathrm{OH}^{-}\right) & \longrightarrow \mathrm{OH}^{\cdot} \\
\mathrm{e}^{-}+\mathrm{O}_{2} & \longrightarrow \mathrm{O}_{2}^{-}
\end{aligned}
$$

The other authors also achieved the similar results in the nanohybrids of $\mathrm{ZnO} / \mathrm{CNC}$ and $\mathrm{ZnO} /$ reduced graphene oxide (RGO) [29] (Table 3). It is noted that the photocatalytic activity of the $\mathrm{ZnO} / \mathrm{CNC}-1.0$ nanohybrid was higher than 


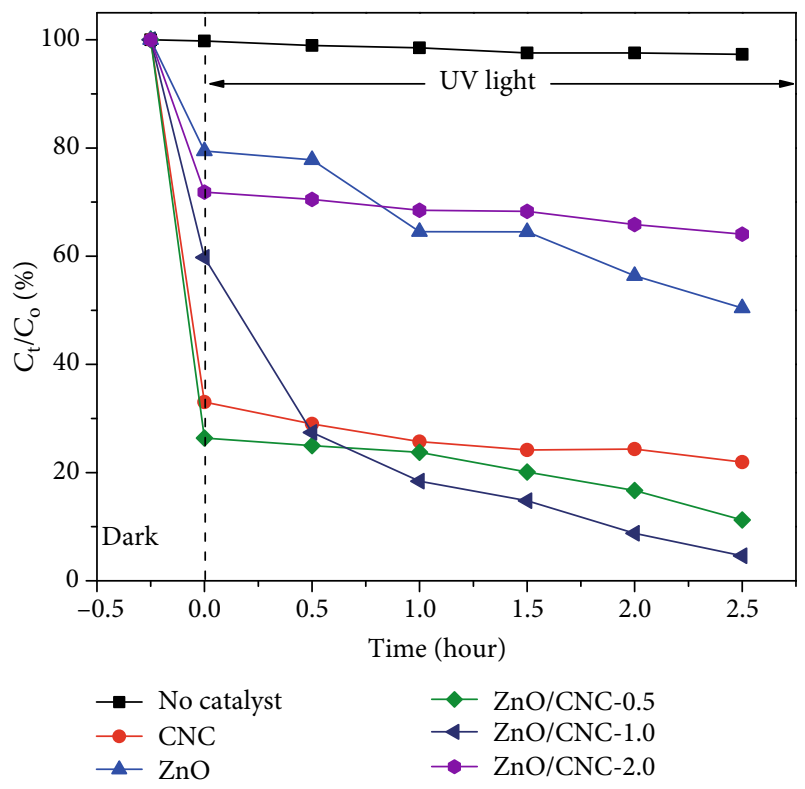

Figure 10: Photocatalytic and adsorption activity of $\mathrm{ZnO}$ and $\mathrm{ZnO} / \mathrm{CNC}$ nanohybrids.

TABLE 3: The comparison of MB photocatalytic activity of the various $\mathrm{ZnO} / \mathrm{CNC}$ nanohybrids.

\begin{tabular}{lcc}
\hline Materials & $\begin{array}{c}\text { The apparent } \\
\text { first-order rate } \\
\text { constant }\left(\mathrm{min}^{-1}\right)\end{array}$ & Ref. \\
\hline ZnO/CNC-1.0 & 0.0157 & $\begin{array}{c}\text { This } \\
\text { study }\end{array}$ \\
$\begin{array}{l}\text { ZnO nanoparticles coated on } \\
\text { nanocellulose from oil palm } \\
\text { empty fruit bunches }\end{array}$ & 0.0019 & {$[22]$} \\
$\begin{array}{l}\text { Sheet like(ZnO-CNC) nanohybrid } \\
\text { synthesized by using hydrothermal } \\
\text { method }\end{array}$ & 0.016 & {$[30]$} \\
$\begin{array}{l}\text { Reduced graphene oxide-ZnO } \\
\text { nanorod composites }\end{array}$ & 0.039 & {$[29]$} \\
$\begin{array}{l}\text { ZnO/CNC synthesized by using } \\
\text { hydrothermal method }\end{array}$ & 0.028 & {$[31]$} \\
$\begin{array}{l}\text { ZnO-cellulose nanocomposite films } \\
\text { from a cellulose-NaOH/urea/zincate } \\
\text { solution }\end{array}$ & 0.046 & {$[32]$} \\
\hline
\end{tabular}

that for $\mathrm{ZnO}$ nanoparticles coated on nanocellulose from oil palm empty fruit bunches [22].

In resuming results of both photocalytic and adsorption activities, the higher photocatalytic ability of $\mathrm{ZnO} / \mathrm{CNC}$ nanohybrids was obtained, the lower adsorption activity was observed.

\section{Conclusions}

Using a facile, one-step synthesis route, $\mathrm{ZnO} / \mathrm{CNC}$ nanohybrids possessing high thermal stability were obtained. The $\mathrm{ZnO}$ nanocrystals of $50 \mathrm{~nm}$ dispersed quite homogeneously around the CNC due to the strong electrostatic interactions between $\mathrm{Zn}^{2+}$ ions and carboxyl groups of CNC. Moreover, the results also gave the evidence that the degradation of $\mathrm{MB}$ was contributed not only by the adsorption ability of $\mathrm{CNC}$ but also by the photocatalytic activity of $\mathrm{ZnO}$. The competition between these two processes depends on the concentration ratio of zinc-precursor $\mathrm{Zn}\left(\mathrm{NO}_{3}\right)_{2} \cdot 6 \mathrm{H}_{2} \mathrm{O}$ and $\mathrm{CNC}$. The $\mathrm{MB}$ photodegradation of $\mathrm{ZnO} / \mathrm{CNC}-1.0$ was obtained as high as $95 \%$ during $150 \mathrm{~min}$. Depending on the purpose of organic dye treatment, it was observed that the yield of adsorption and photocatalytic process could be controlled by changing the concentration ratio of zincprecursor $\mathrm{Zn}\left(\mathrm{NO}_{3}\right)_{2} \cdot 6 \mathrm{H}_{2} \mathrm{O}$ and $\mathrm{CNC}$ from 0.5 to 1.0. Such nanohybrids with improved properties show great potential for waste water treatment.

\section{Data Availability}

The data used to support the findings of this study are included within the article.

\section{Conflicts of Interest}

The authors declare that they have no conflicts of interest.

\section{Acknowledgments}

This research is funded by Vietnam National University Ho Chi Minh City (VNU-HCM) under grant number 5622018-18-01.

\section{References}

[1] A. Dufresne, "Cellulose nanomaterial reinforced polymer nanocomposites," Current Opinion in Colloid \& Interface Science, vol. 29, pp. 1-8, 2017.

[2] M. Fardioui, M. E. M. Mekhzoum, A. . K. Qaiss, and R. Bouhfid, "Bionanocomposite materials based on chitosan reinforced with nanocrystalline cellulose and organo-modified montmorillonite," in Nanoclay Reinforced Polymer Composites: Nanocomposites and Bionanocomposites, pp. 167-194, Springer, 2016.

[3] P. Dhar, D. Tarafder, A. Kumar, and V. Katiyar, "Effect of cellulose nanocrystal polymorphs on mechanical, barrier and thermal properties of poly (lactic acid) based bionanocomposites," RSC Advances, vol. 5, no. 74, pp. 60426-60440, 2015.

[4] D. Bagheriasl, P. J. Carreau, B. Riedl, and C. Dubois, "Enhanced properties of polylactide by incorporating cellulose nanocrystals," Polymer Composites, vol. 39, no. 8, pp. 26852694, 2018.

[5] L. Ma, Y. Zhang, and S. Wang, "Preparation and characterization of acrylonitrile-butadiene-styrene nanocomposites reinforced with cellulose nanocrystal via solution casting method," Polymer Composites, vol. 38, pp. E167-E173, 2017.

[6] D. Trache, M. H. Hussin, M. K. Haafiz, and V. K. Thakur, "Recent progress in cellulose nanocrystals: sources and production," Nanoscale, vol. 9, no. 5, pp. 1763-1786, 2017.

[7] C. Chen and L. Hu, "Nanocellulose toward advanced energy storage devices: structure and electrochemistry," Accounts of Chemical Research, vol. 51, no. 12, pp. 3154-3165, 2018. 
[8] H. Voisin, L. Bergström, P. Liu, and A. Mathew, "Nanocellulose-based materials for water purification," Nanomaterials, vol. 7, no. 3, p. 57, 2017.

[9] Y.-Y. Li, B. Wang, M. G. Ma, and B. Wang, "Review of recent development on preparation, properties, and applications of cellulose-based functional materials," International Journal of Polymer Science, vol. 2018, Article ID 8973643, 18 pages, 2018.

[10] K. M. Lee, C. W. Lai, K. S. Ngai, and J. C. Juan, "Recent developments of zinc oxide based photocatalyst in water treatment technology: a review," Water Research, vol. 88, pp. 428-448, 2016.

[11] K. Qi, B. Cheng, J. Yu, and W. Ho, "Review on the improvement of the photocatalytic and antibacterial activities of ZnO," Journal of Alloys and Compounds, vol. 727, pp. 792820, 2017.

[12] F. Awan, M. S. Islam, Y. Ma et al., "Cellulose nanocrystal-ZnO nanohybrids for controlling photocatalytic activity and UV protection in cosmetic formulation," ACS Omega, vol. 3, no. 10, pp. 12403-12411, 2018.

[13] F. Wu, "Copper and zin oxide composite nanostructures for solar energy harvesting," in Engineering and Applied Science Theses and Dissertations, Washington University, 2015.

[14] S. Singh, R. Pendurthi, M. Khanuja, S. S. Islam, S. Rajput, and S. M. Shivaprasad, "Copper-doped modified $\mathrm{ZnO}$ nanorods to tailor its light assisted charge transfer reactions exploited for photo-electrochemical and photo-catalytic application in environmental remediation," Applied Physics A, vol. 123, no. 3, p. $184,2017$.

[15] M. Samadi, M. Zirak, A. Naseri, E. Khorashadizade, and A. Z. Moshfegh, "Recent progress on doped $\mathrm{ZnO}$ nanostructures for visible-light photocatalysis," Thin Solid Films, vol. 605, pp. 219, 2016

[16] P. R. Sharma, S. K. Sharma, R. Antoine, and B. S. Hsiao, "Efficient removal of arsenic using zinc oxide nanocrystaldecorated regenerated microfibrillated cellulose scaffolds," ACS Sustainable Chemistry \& Engineering, vol. 7, no. 6, pp. 6140-6151, 2019.

[17] Y. Guan, H. Y. Yu, S. Y. H. Abdalkarim et al., "Green one-step synthesis of $\mathrm{ZnO} /$ cellulose nanocrystal hybrids with modulated morphologies and superfast absorption of cationic dyes," International Journal of Biological Macromolecules, vol. 132, pp. 51-62, 2019.

[18] M. Ul-Islam, W. A. Khattak, M. W. Ullah, S. Khan, and J. K. Park, "Synthesis of regenerated bacterial cellulose-zinc oxide nanocomposite films for biomedical applications," Cellulose, vol. 21, no. 1, pp. 433-447, 2014.

[19] W.-L. Zheng, W. L. Hu, S. Y. Chen, Y. Zheng, B. H. Zhou, and H. P. Wang, "High photocatalytic properties of zinc oxide nanoparticles with amidoximated bacterial cellulose nanofibers as templates," Chinese Journal of Polymer Science, vol. 32, no. 2, pp. 169-176, 2014.

[20] S. Azizi, M. Ahmad, M. Mahdavi, and S. Abdolmohammadi, "Preparation, characterization, and antimicrobial activities of zno nanoparticles/cellulose nanocrystal nanocomposites," BioResources, vol. 8, no. 2, p. 11, 2013.

[21] M. S. Jahan, A. Saeed, Z. He, and Y. Ni, "Jute as raw material for the preparation of microcrystalline cellulose," Cellulose, vol. 18, no. 2, pp. 451-459, 2011.

[22] K. Lefatshe, C. M. Muiva, and L. P. Kebaabetswe, "Extraction of nanocellulose and in-situ casting of $\mathrm{ZnO} /$ cellulose nano- composite with enhanced photocatalytic and antibacterial activity," Carbohydrate Polymers, vol. 164, pp. 301-308, 2017.

[23] H.-Y. Yu, G. Y. Chen, Y. B. Wang, and J. M. Yao, "A facile onepot route for preparing cellulose nanocrystal/zinc oxide nanohybrids with high antibacterial and photocatalytic activity," Cellulose, vol. 22, no. 1, pp. 261-273, 2015.

[24] M. Wada, L. Heux, and J. Sugiyama, "Polymorphism of cellulose I family: reinvestigation of cellulose IVI," Biomacromolecules, vol. 5, no. 4, pp. 1385-1391, 2004.

[25] S. Nam, A. D. French, B. D. Condon, and M. Concha, "Segal crystallinity index revisited by the simulation of X-ray diffraction patterns of cotton cellulose I $\beta$ and cellulose II," Carbohydrate Polymers, vol. 135, pp. 1-9, 2016.

[26] B. K. Sharma, N. Khare, S. K. Dhawan, and H. C. Gupta, "Dielectric properties of nano $\mathrm{ZnO}$-polyaniline composite in the microwave frequency range," Journal of Alloys and Compounds, vol. 477, no. 1-2, pp. 370-373, 2009.

[27] Q.-S. Liu, M. F. Zhu, W. H. Wu, and Z. Y. Qin, "Reducing the formation of six-membered ring ester during thermal degradation of biodegradable PHBV to enhance its thermal stability," Polymer Degradation and Stability, vol. 94, no. 1, pp. 18-24, 2009.

[28] A. Balcha, O. P. Yadav, and T. Dey, "Photocatalytic degradation of methylene blue dye by zinc oxide nanoparticles obtained from precipitation and sol-gel methods," Environmental Science and Pollution Research, vol. 23, no. 24, pp. 25485-25493, 2016.

[29] K. Huang, Y. H. Li, S. Lin et al., "A facile route to reduced graphene oxide-zinc oxide nanorod composites with enhanced photocatalytic activity," Powder Technology, vol. 257, pp. 113119, 2014.

[30] S. Y. H. Abdalkarim, H. Y. Yu, C. Wang, L. X. Huang, and J. Yao, "Green synthesis of sheet-like cellulose nanocrystalzinc oxide nanohybrids with multifunctional performance through one-step hydrothermal method," Cellulose, vol. 25, no. 11, pp. 6433-6446, 2018.

[31] G. Wei, H. F. Zuo, Y. R. Guo, and Q. J. Pan, "Synthesis of ZnO with enhanced photocatalytic activity: a novel approach using nanocellulose," BioResources, vol. 11, no. 3, pp. 6244-6253, 2016.

[32] F. Fu, J. Gu, X. Xu et al., "Interfacial assembly of $\mathrm{ZnO}$-cellulose nanocomposite films via a solution process: a one-step biomimetic approach and excellent photocatalytic properties," Cellulose, vol. 24, no. 1, pp. 147-162, 2017. 